\title{
BEAUTY IS NOT ONLY SKIN DEEP: FOOD ETHICS AND CONSEQUENCES TO THE VALUE CHAIN
}

Vivian Lara Silva ${ }^{1}$, Marcia Gabriela C. Kasemodel, Fausto Makishi, Roberta de Castro Souza Pião, Vinícius Machado dos Santos Universidade de São Paulo - USP, São Paulo, (Brasil)

Universidade Federal de Minas Gerais - UFMG, Minas Gerais, (Brasil)

\section{ARTICLE DETAILS}

\section{Article history:}

Received: 18 December 2018

Accepted: 21 July 2019

Available online August: 01 th 2019

Double Blind Review System

\section{Scientific Editor}

Ilan Avrichir

\section{Keywords}

Food products;

Innovation:

Value creation;

Labeling Food Strategy

\begin{abstract}
The contemporary context in which the food industry is set up instigates a new product conception towards food ethics. However, how effectively does this perspective materialize on the gondolas of retail chains? In order to bring some elements to discussion, this article presents an exploratory study based on the decoding of information contained in food labels marketed in Brazil. In total, 287 labels regarding four categories (juices, snacks, chocolates, and yogurt) were analyzed using the Reverse Engineering methodology. The results indicate a movement of brand differentiation structured in actions conducted inside (a result of product and process engineering) and outside (regarding relationship engineering along the value chain). In other words, the internalization of innovations in products and processes (inside perspective) and; the development of vertical cooperation and coordination relations outside the company (outside perspective). In this sense, participation in globally connected markets is described as a driver of differentiation strategies regarding ethical aspects in the food processing industry and has direct effects on the vertical structures of firms, as suggested by the value chain literature.
\end{abstract}

\section{Introduction}

The concept of food ethics was originally associated with guaranteeing availability, accessibility, variety, and safety of food and beverage products (Korthals, 2001; Deblonde, de Graaff \& Brom, 2007; De Tavernier, 2012). However, while some producers, processors, and retailers remain concerned with these conventional perspectives, consumer drivers point to the need for a different approach in terms of food ethics (Hepting, Jaffe, \& Maciag, 2014). Indeed, contemporary consumers are increasingly demanding products that promote their own health and wellness, in alignment with animal and environmental welfare, as well as fair labor conditions in a global context related to the food value chain (Korthals, 2001; Severo, Guimarães \& Dorion, 2018). The growth of both ethical consumption and social and political participation has brought greater pressure on the food industry to act socially and environmentally responsible (Early, 2002). In addition to assuring food security and safety, producers, processors, and retailers must consider ethical questions raised by particular
Beauty is not only skin deep: Food ethics and consequences to the value chain ${ }^{2}$ production practices and conditions in the food value chain (Coff, 2013; Deblonde, de Graaff \& Brom, 2007). These questions are associated with foodrelated illnesses, such as obesity, cancer, and cardiovascular diseases. Moreover, they are associated with social and environmental concerns, such as fair trade, organic labeling, and cleaner production (Silva, Sereno \& Sobral, 2018).

Furthermore, with the increasing competitiveness in the food industry, food ethics may be a part of a firm's differentiation strategy (Grunert, Hieke \& Wills, 2014; Silva, 2017), creating a competitive advantage by promoting their brand reputation and positioning their products as socially and environmentally responsible (Boehe \& Cruz, 2010). Brand reputation increases the value perceived by consumers, strengthening loyalty, advocacy, and identification with the firm (Du, Bhattacharya \& Sen, 2007). Additionally, a differentiation strategy based on food ethics provides a better understanding of a more responsive demand in terms of needs, rationales and beliefs (Kasemodel et al., 2016).

\footnotetext{
${ }^{1}$ Contato do autor - Email: vivianlara@usp.br

DOI: 10.18568/internext.v14i3.489

2 Paraphrasing the song 'Beauty Is Only Skin Deep', recorded on 1966 by the American vocal group Temptations.
} 
However, in order to act on their ethical preferences, consumers require information (Irvine, 2013). The direct contact between food production and consumption, which originally formed the basis of trust, has largely disappeared (Brom, 2000). With this increasing distance between producers, processors, and consumers, the way consumers perceive food and beverage products and build trust has changed. The most useful information for consumers purchasing decisions comes through labeling (Hepting, Jaffe \& Maciag, 2014, Verbeke \& Ward, 2006). Food labels have been largely considered a topic of study in the literature, regarding, for instance, labeling formats and their influence in consumer decision (Caswell \& Mojduszka, 1996; Feunekes et al. 2008). Additionally, following the contemporary panorama related to food processing and consumption, there is an increasing interest towards receptivity, perception, and willingness to pay a premium price for labels that indicate food ethics. Take for instance Loureiro \& Lotade (2005), Grunert, Hieke \& Wills (2014), and Bissinger \& Leufkens (2017). However, an open question remains unexplored in the literature regarding food ethics and labeling: how does the concept of food ethics materialize on processed food product labels? What can they reveal about the new strategic positioning of the food industry vis-a-vis the contemporary moment we live in? Starting from this frame, the main purpose of this article was to understand how the concept of food ethics materializes in terms of food and beverage products launches in Brazil by means of a label analysis using Reverse Engineering methodology. The remainder of this article is structured as follows. Next, a theoretical background regarding food ethics is presented. In the third section, the food ethics market is described. In the fourth section, the label analysis performed is detailed regarding material and methods employed; while in the fifth section, the results obtained are discussed. Lastly, managerial implications and final remarks are presented.

\section{Food Ethics}

Over two centuries of history, the food industry has reinvented itself substantially in terms of the orientation of its core business: from vegetable and animal raw material processer with the main purpose of safety and conservation in the early 19th century, to supplier of safe, practical and convenient food, ensuring sensory, nutritional and functional aspects (Aguilera, 2006). Despite this observed progress, an important share of global consumers remains unsatisfied, revealing complex consumption drivers associated with processed food (Silva, Sereno \& Sobral, 2018).

In this context, the food industry's core business is no longer about processing to preserve or ensure safety, considered initial attributes of the industry. Nor is it about processing to exclusively enhance flavor and favor convenience, or even to contribute to health and well-being. Increasingly and among all economies, whether developed or emerging countries, consumers demand a product that meets all of these characteristics, while benefiting the health of society in which the industry operates (Silva, 2017). This concept is referred to as food ethics, comprising three main levels of consumer concerns (Brom, 2000), Figure 1.

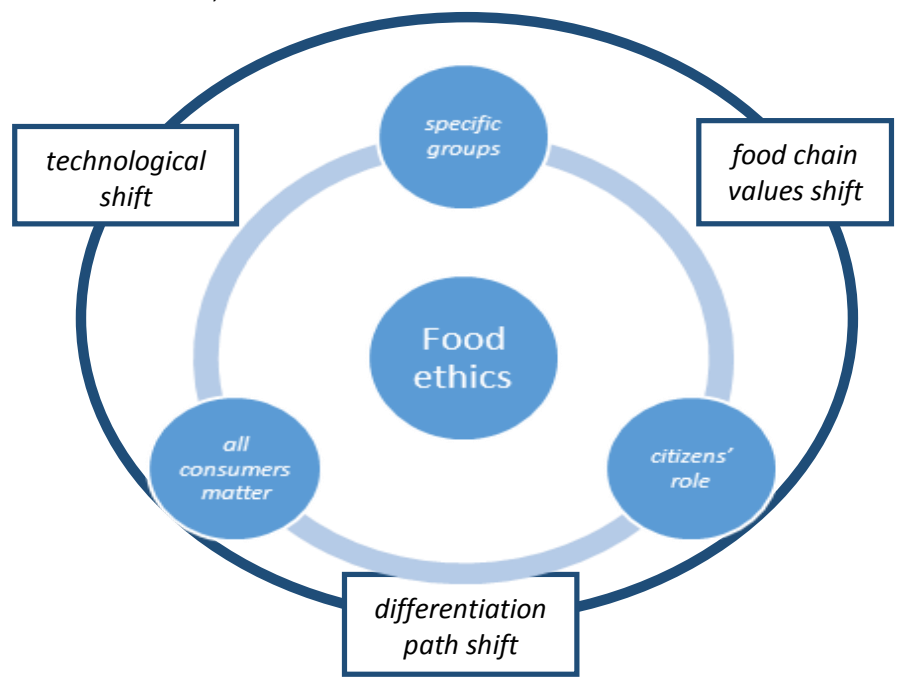

Figure 1. Food ethics: product, society and environment. Source: Based on Brom (2000). 
The first level is related to consumers. It includes concerns such as food safety, i.e. "when all people, at all times, have physical and economic access to sufficient, safe and nutritious food that meets their dietary needs and food preferences for an active and healthy life" (World Food Summit, 1996).

The second level is related to groups of consumers, considering the way they want to live their life as well as their own life plan. For instance, those who are vegan can only live according to their own value system when they know that their food products do not contain inputs of animal origin (Brom, 2000).

The third level is related to consumers in their role as citizens. These concerns are related to ideas about a good society, considering the impact products have on both society and the environment (Brom, 2000). The social aspect involves the promotion of sustainable development and the empowerment of local communities (Silva, Sereno \& Sobral, 2018). In turn, the environmental aspect could be associated with agroforestry systems, conscious use of natural resources, reduction of carbon footprint, management of water resources, encouragement of the principles of reduction, recycling, and reuse, among other concepts (Melo et al., 2018, Saes et al., 2014).

These three concerns are closely related to certification and standards. Take for instance the case of better-for-you food products with the substitution or removal of fat, sugar, and/or sodium, as well as naturally-healthy food products with natural and whole ingredients (Viana, Silva \& Trindade, 2014). In turn, Organic, Fair Trade, UTZ-Certified, Rainforest Alliance are some of the most important seals regarding environmental and social requirements (Vecchio \& Annunziata, 2015). In this sense, Grunert, Hieke \& Wills (2014) argue that consumers relate sustainability mainly to environmental issues, despite the importance of social aspects; while Janßen \& Langen (2017) consider that aspects such as animal friendliness and local production are going to receive more importance in the near future.

From these consumer concerns, three major shifts are expected. The first shift involves food value chains (Deblonde, de Graaff \& Brom, 2007). The food sector has to open up in order to bridge the gap between producers and consumers and to respond to problems of mutual distrust. In this context, transparency and communication are key (Brom et al., 2004, Deblonde, de Graaff \& Brom, 2007).

The second shift involves a technological paradigm (Deblonde, de Graaff \& Brom, 2007; Silva, Sereno \& Sobral, 2018). The technological and scientific approach seems disconnected to the role of food in people's lifes (Beekman, 2000; Brom, 2000; Silva, Sereno and Sobral 2018). According to Deblonde, de Graaff \& Brom (2007), a mental gap has grown between actual food production methods and consumers' ideas about them. Many consumers have a romantic picture of food production that is often reenforced by food marketing. When - particularly in situations of food crises - they are confronted with the reality of food production, feeling alienated (Deblonde, de Graaff \& Brom, 2007). This leads to the critical understanding that the fascination for a certain process by industry professionals does not necessarily guarantee added value from the consumer's perspective (Saguy et al., 2013).

In turn, this frame leads to the third shift, which involves origin concern and a new differentiation path in the longing for a sustainable competitive advantage. The contemporary challenging situation urges the development of new processes and technologies considering present-day consumption drivers associated with processed food. This is important for the food industry to reinvent itself and to understand that more than creating textures, the opportunity is also to preserve and enhance attributes derived from raw materials and from the relationships established throughout the value chain in which the food industry operates (Silva, Sereno and Sobral 2018).

This new differentiation path is aligned to the perspective that a "food product has a lot of value, also referring to where (and how) it comes" (Lopez, 2014). This results in the opportunity for technological and scientific developments to be aligned with the social dynamics of the food industry (Kasemodel et al., 2016).

Indeed, differentiation strategies could go beyond aspects assured inside or within technological limits (Silva, Sereno \& Sobral, 2018). So that, a considerable part of both value and quality of the food product could encompass a true story behind processing (Mintel, 2016), related to the socio-environmental context regarding origination, processing, distribution and/or commercialization (Humphrey \& 
Memedovic, 2006, Henson \& Humphrey, 2009, Saes et al., 2014).

Considering the concept of food ethics presented in this section, a two-branch decision model regarding differentiation based on food ethics could be defined (Figure 2). This decision model is comprised of an inside perspective, which includes rethinking product, process, marketing, and packaging, seeking to develop products that are healthier and more sustainable, following new bases of communication with the consumer. Additionally, the decision model is also comprised of an outside perspective, which is related to rethinking food industry relationships along the value chain, regarding the quality of relationships established by the industry with its stakeholders (Silva, Sereno and Sobral 2018; Silva, 2017).

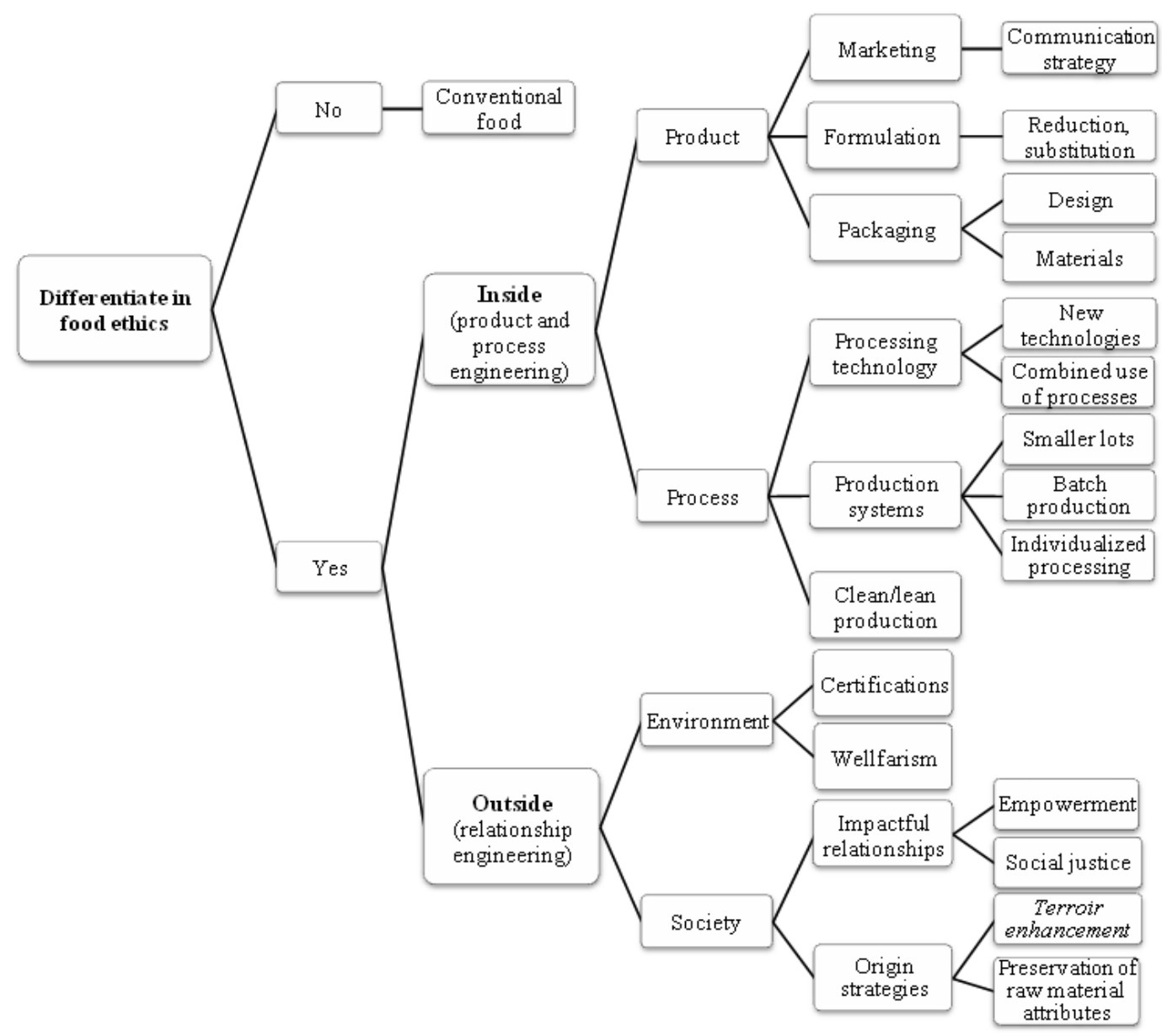

Figure 2. Food ethics differentiation in a decision tree model. Source: Based on Silva (2017).

\section{The Food Ethics Market}

With consumers demanding products that promote health and wellness, animal and environmental welfare, as well as fair labor conditions in a global context, the number of food and beverage products launched with an ethical claim has increased over the years.

Many brands are using ethical descriptions, certifications, and seals on product packaging in order to communicate socially and environmentally responsible practices according to market research performed by Mintel, a global market intelligence agency. In 2010, 1.362 food and beverage products marketed as ethical were launched worldwide as reported in the market analysis conducted by Mintel (2017). In 2016, this number reached 7.441 and a total of 28.082 products with an ethical claim were launched worldwide between 2010 and 2016 (Mintel, 2017). The most representative countries in terms of food and beverage product launches with an ethical claim included Germany, USA, and France, which 
together accounted for over $36 \%$ of all launches in the category.

The highlighted segments considering number of ethical food and beverage product launches worldwide were the beverages (including hot beverages, juices and fruit beverages, alcoholic beverages, waters and others), chocolate products and bakery products (including breads, cakes, crackers and cookies) segments (Table 1), contributing with over $68 \%$ of all ethical food and beverage product launches in 2016 (Mintel, 2017). Concerning growth rates, desserts and ice creams, fruit and vegetable products, and bakery products were the most relevant segments between 2010 and 2016 , presenting an average growth rate of $61 \%, 56 \%$ and $49 \%$ per year, respectively.

Table 1. Ethical food and beverage product launches by category (2010-2016).

\begin{tabular}{|c|c|c|c|c|c|c|c|}
\hline Category & 2010 & 2011 & 2012 & 2013 & 2014 & 2015 & 2016 \\
\hline Hot beverages & 488 & 598 & 632 & 1239 & 144 & 1652 & 1697 \\
\hline Chocolate products & 273 & 258 & 419 & 932 & 1503 & 1764 & 2165 \\
\hline Bakery products & 92 & 115 & 150 & 331 & 527 & 763 & 1029 \\
\hline $\begin{array}{l}\text { Desserts and ice } \\
\text { creams }\end{array}$ & 25 & 62 & 51 & 179 & 289 & 365 & 438 \\
\hline Appetizers & 51 & 74 & 81 & 149 & 180 & 281 & 339 \\
\hline Dairy products & 48 & 53 & 117 & 115 & 177 & 145 & 183 \\
\hline $\begin{array}{l}\text { Sauces and } \\
\text { condiments }\end{array}$ & 60 & 90 & 59 & 138 & 139 & 176 & 174 \\
\hline $\begin{array}{l}\text { Ready to consume } \\
\text { beverages }\end{array}$ & 35 & 45 & 67 & 156 & 145 & 173 & 191 \\
\hline Sides & 48 & 64 & 53 & 87 & 96 & 151 & 217 \\
\hline $\begin{array}{l}\text { Juices and fruits } \\
\text { beverages }\end{array}$ & 34 & 59 & 48 & 108 & 112 & 136 & 132 \\
\hline $\begin{array}{l}\text { Fruits and } \\
\text { vegetables } \\
\text { products }\end{array}$ & 10 & 32 & 41 & 88 & 73 & 104 & 146 \\
\hline Breakfast cereals & 32 & 14 & 23 & 60 & 80 & 118 & 98 \\
\hline $\begin{array}{l}\text { Fish, meat, and egg } \\
\text { products }\end{array}$ & 36 & 19 & 49 & 51 & 64 & 90 & 104 \\
\hline $\begin{array}{l}\text { Sugars and } \\
\text { sweetners }\end{array}$ & 24 & 23 & 41 & 45 & 49 & 80 & 85 \\
\hline Other beverages & 12 & 29 & 24 & 36 & 38 & 51 & 36 \\
\hline Alcoholic beverages & 11 & 19 & 27 & 36 & 53 & 45 & 41 \\
\hline Candys and gums & 10 & 21 & 31 & 39 & 37 & 27 & 53 \\
\hline $\begin{array}{l}\text { Ready to consume } \\
\text { meals }\end{array}$ & 19 & 18 & 18 & 34 & 31 & 27 & 30 \\
\hline Baby food & 2 & 3 & 13 & 13 & 11 & 44 & 49 \\
\hline
\end{tabular}

Note. Source: Retrieved from Mintel. Global New Product Database. (2017, April 10).

Regarding developing economies, Brazil presented a relevant performance considering the ethical food and beverage market. In 2010, 27 food and beverage products marketed as ethical were launched in the country (Mintel, 2017). In 2016, this number reached 85 , so that 443 products with an ethical claim were launched in Brazil between 2010 and 2016 (Mintel, 2017). The average growth rate of launches of food and beverage products with an ethical claim was of $21 \%$ per year in the country. Brazil was only surpassed by the USA, UK, Germany, and France in terms of ethical food and beverage product launches.
Concerning product segments, beverages (including hot beverages, juices and fruit beverages, alcoholic beverages, and waters), chocolate products, bakery products (including categories such as breads, cakes, crackers and cookies), desserts, ice creams and dairy products consisted of the most representative considering ethical food and beverage product launches in Brazil in 2016 (Table 2).

When combined, these segments contributed to over $51 \%$ of all ethical food and beverage product launches in the country (Mintel, 2017). 
Table 2. Brazilian ethical food and beverage product launches by category (2010-2016).

\begin{tabular}{|c|c|c|c|c|c|c|c|}
\hline Category & 2010 & 2011 & 2012 & 2013 & 2014 & 2015 & 2016 \\
\hline Hot beverages & 3 & 20 & 6 & 18 & 27 & 20 & 32 \\
\hline $\begin{array}{l}\text { Desserts and } \\
\text { ice creams }\end{array}$ & 0 & 0 & 1 & 3 & 14 & 14 & 12 \\
\hline $\begin{array}{l}\text { Chocolate } \\
\text { products }\end{array}$ & 2 & 2 & 9 & 7 & 3 & 9 & 14 \\
\hline $\begin{array}{l}\text { Bakery } \\
\text { products }\end{array}$ & 3 & 1 & 6 & 6 & 4 & 13 & 9 \\
\hline $\begin{array}{l}\text { Fish, meat and } \\
\text { egg products }\end{array}$ & 3 & 4 & 6 & 4 & 8 & 2 & 1 \\
\hline Appetizers & 4 & 1 & 5 & 3 & 3 & 6 & 4 \\
\hline $\begin{array}{l}\text { Sauces and } \\
\text { condiments }\end{array}$ & 3 & 1 & 4 & 7 & 2 & 2 & 1 \\
\hline Dairy products & 0 & 0 & 4 & 5 & 0 & 2 & 3 \\
\hline Sides & 2 & 0 & 2 & 2 & 0 & 7 & 0 \\
\hline $\begin{array}{l}\text { Juices and } \\
\text { fruit } \\
\text { beverages }\end{array}$ & 0 & 0 & 0 & 6 & 3 & 2 & 2 \\
\hline $\begin{array}{l}\text { Breakfast } \\
\text { cereals }\end{array}$ & 0 & 1 & 1 & 2 & 1 & 3 & 0 \\
\hline Fruits & \multirow[b]{2}{*}{1} & \multirow[b]{2}{*}{1} & \multirow[b]{2}{*}{1} & \multirow[b]{2}{*}{1} & \multirow[b]{2}{*}{0} & \multirow[b]{2}{*}{2} & \multirow[b]{2}{*}{4} \\
\hline $\begin{array}{l}\text { and } \\
\text { vegetables } \\
\text { products }\end{array}$ & & & & & & & \\
\hline$\frac{\text { Sugar }}{\text { and sweetners }}$ & 0 & 0 & 2 & 1 & 2 & 2 & 1 \\
\hline $\begin{array}{l}\text { Ready to } \\
\text { consume } \\
\text { meals }\end{array}$ & 0 & 1 & 1 & 4 & 1 & 0 & 0 \\
\hline $\begin{array}{l}\text { Other } \\
\text { beverages }\end{array}$ & 0 & 1 & 1 & 0 & 0 & 2 & 1 \\
\hline $\begin{array}{l}\text { Alcoholic } \\
\text { beverages }\end{array}$ & 0 & 1 & 1 & 0 & 1 & 1 & 1 \\
\hline $\begin{array}{l}\text { Candys } \\
\text { and gums }\end{array}$ & 0 & 0 & 1 & 3 & 0 & 0 & 0 \\
\hline Soups & 0 & 0 & 1 & 0 & 0 & 0 & 0 \\
\hline Waters & 0 & 0 & 0 & 1 & 0 & 0 & 0 \\
\hline
\end{tabular}

Source: Retrieved from Mintel. Global New Product Database. (2017, April 10).

Retrieved from http://brasil.mintel.com/gnpd-banco-de-datos-de-novos-productos.

\section{Materials and Methods}

\section{Label's role in consumer choice}

We argue that labels might be a source of accessible information in a quick manner and with no significant costs, revealing a fertile territory - quite unexplored for the conduction of a comparative analysis of strategic positioning regarding companies and their brands, by decoding graphic and descriptive information.

The guarantee of physical, chemical and microbiologic integrity drives many efforts in the development of food products. Since improvement in the filling process, use of established multilayer packaging, up until the emerging technologies of active packaging, the role of packaging in foods has developed mainly due to shelf life maintenance (Smith, Ramaswamy \& Simpson, 1990; Sarantopoulos, De Oliveira \& Canavesi, 2001; Marsh \& Bugusu, 2007; Ahvenainen, 2012; Robertson, 2012;).

Furthermore, labels appear to be one of the most important factors in consumer purchasing decisions (Prendergast \& Pitt, 1996; Nancarrow, Wright \& Brace, 1998; Rettie \& Brewer, 2000; Silayoi \& Speece, 2007). As observed by Silayoi and Speece (2007), changes that occurred in the past decades in retail format services led packaging to increase its key characteristic as "shelf 
salesman" at the point of purchase. Labeling has become a determinant element in the strategy of adding value to a food or beverage product (Nancarrow, Wright \& Brace, 1998).

Labeling and packaging are related to marketing, management, advertising, as well as communication, providing a very rich field of studies for various methodologies. Conjoint analysis (Green \& Srinivasan, 1978; 1990; Grunert et al., 1996; Van Der Pol \& Ryan, 1996; Silayoi \& Speece, 2007), focus groups (Brug et al. 1995; Neumark-Sztainer, 1999) and cluster analysis (Rodrigues et al., 2016) are examples of these methodologies. Sophisticated tools have also been incorporated in this field, such as consumer sensory neuroscience (Zatorre, 2005). These efforts seek to broadly identify attributes that are valued by consumers regarding labeling of processed food in terms of the influence of shapes, materials, colors, and images on consumer decision. Particularly, labels take on the important task of informing nutritional and safety values, reliability, functionality, convenience and social and environmental commitment associated with a product or company.

\section{Label claims analysis and reverse engineering}

An exploratory study was conducted with the purpose of assessing how the concept of food ethics materializes in terms of food and beverage product launches in Brazil. A systematic analysis of the information contained in labels was performed considering four categories: juices, snacks, chocolates, and yogurts, due to their relevance in the total number of launches worldwide and in Brazil. In total, 278 labels were analyzed, including 36 juice labels, 115 snack labels, 12 chocolate labels, and 115 yogurt labels. In total, more than 2500 entries concerning label claims or affirmations were selected. The Brazilian supermarket sector is among the fastest growing, followed by Internet sales. In the middle of the economic and political crisis that hit the country, revenues in 2017 grew $6.6 \%$, reaching $\mathrm{R} \$ 41.8$ billion, approximately US\$ 12.7 billion, according to the Network and Associations Research of the Brazilian Association of Supermarkets. Almost $50 \%$ of the stores are located in the southeast region and $30 \%$ of the country's supermarket stores are concentrated in the state of São Paulo. On average, these stores have 12 to 16 checkouts points (Abras, 2019).

Data collection took place in April 2014 at an establishment with 20-checkouts points, located in the city of Pirassununga, in the state of São Paulo, Brazil. The establishment, which will have its identity preserved by the request of its managers, is part of a medium-sized retail network with operations restricted to the Center-East region of the State of São Paulo, with strategic positioning in terms of cost leadership. Pirassununga has 70,000 inhabitants, an HDI of 0.801, per capita income of $\mathrm{R} \$ 1.086,22$ and more than $54 \%$ of the population has an average level of schooling, 17\% with higher education. Pirassununga is located in the central region of the state, in a region with a strong vocation for agribusiness, $200 \mathrm{~km}$ from the city of São Paulo.

The authors acknowledge that the sociodemographic characteristics are above the average of the country where the research was performed, but not so far from the state of São Paulo. We point out that Brazil is a country of inequality and heterogeneity, and it is very difficult and costly to conduct research that represents the consumption behavior of the country as a whole. The Brazilian average Human Development Index (HDI) is 0.727 and the per capita income of $\mathrm{R} \$$ 793.87. In the state of São Paulo, the HDI is 0.783 and the per capita income is of $\mathrm{R} \$ 1,084.46$. One possible implication of this decision reflects the fact that, in more sophisticated markets, such as Pirassununga and São Paulo, the cost factor does not represent such a strong interference in the consumer decision-making process. In this case, aspects related to ethics may be an element of greater importance in the differentiation strategies adopted by brands. As a favorable argument, we highlight that the state of São Paulo has one of the highest processed food per capita consumptions in the country (Vale et al., 2019). In addition, the data collection site is within the range of distribution of the main food and beverage manufacturers in Brazil.

A content analysis was performed on food labels traded in Brazilian retail (Hodgkins et al., 2012; Shine et al., 1997; Chan, Patch \& Williams, 2005). From the information contained in labels, the data were classified according to the product, category, brand, manufacturer, label claims and composition. Additionally, label analysis was performed considering exclusively the information presented in labels. The observed variables included legal denominations (i.e. classification of the product according to the legislation), label claims (eg "natural", "premium", "handmade", "enriched with ..."), seals/certifications (e.g. organic, and fair trade) and other verbal statements permitted by Brazilian law. A synthesis of the observed variables is shown in Table 3.

The analysis of an orange juice label was used as an example and the following information was collected: "100\% juice", "keep refrigerated", "real orange", "cold aseptic packaging", "new formula", "with Orange gum", 
"without added sugar", "without conservatives", "source of C vitamin", "from the farm", in addition to legal information on composition, volumetric content, nutritional table, date of manufacture and expiration date. Label analysis was complemented by a review and analysis of publicity materials and articles published in the field. Through this method, the differentiation strategy adopted in each product analyzed was categorized according to marketing or publicity appeals, new formulations, new product presentation (in terms of packaging and design), new processing technologies and new supply chain designs.

Table 3. Variables observed in food labels.

\begin{tabular}{|c|c|}
\hline Asset & Observed variables (label claims) \\
\hline Flavor & $\begin{array}{l}\text { Good tasty } \\
\text { Gourmet } \\
\text { Artificial aromatized }\end{array}$ \\
\hline Nutrition and Health & $\begin{array}{l}\text { Healthier } \\
\text { Vitamin source } \\
\text { Rich in ... } \\
\text { With fibers } \\
\text { Less sugar, sugar free } \\
\text { Diet } \\
\text { Ligh } \\
100 \% \text { natural } \\
\text { No transgenic } \\
\text { New formula }\end{array}$ \\
\hline Publicity e marketing & $\begin{array}{l}\text { Subscribe on the site } \\
\text { Follow our social network } \\
\text { Participate in the promotion } \\
\text { Follow our site } \\
\text { To know more access ... }\end{array}$ \\
\hline $\begin{array}{l}\text { Processing or } \\
\text { manufacturing mode }\end{array}$ & $\begin{array}{l}\text { Handmade /home made } \\
\text { Cold aseptic packaging } \\
\text { No conservatives } \\
\text { Vacuum packaging } \\
\text { Aroma pack } \\
\text { Roast - not fried }\end{array}$ \\
\hline $\begin{array}{l}\text { Origins and } \\
\text { supply chain }\end{array}$ & $\begin{array}{l}\text { Made in... } \\
\text { Lawful } \\
\text { From the farm } \\
\text { Product of family farming } \\
\text { Origins } \\
\text { Special safra }\end{array}$ \\
\hline $\begin{array}{l}\text { Philanthropy or social } \\
\text { action }\end{array}$ & $\begin{array}{l}\text { Fair trade } \\
\text { Producer help program } \\
\text { Cocoa plan }\end{array}$ \\
\hline Convenience & $\begin{array}{l}\text { Opens easy } \\
\text { Ready for consumption } \\
\text { Easy to prepare }\end{array}$ \\
\hline Environmental & $\begin{array}{l}\text { Sustainability program } \\
\text { Biodegradable packaging }\end{array}$ \\
\hline $\begin{array}{ll}\text { Stamps } & \text { and } \\
\text { certificates } & \end{array}$ & $\begin{array}{l}\text { Organic certification } \\
\text { Rainforest aliance } \\
\text { Ecocert } \\
\text { Fsc - forest stewardship council } \\
\text { Abic - brazilian coffee industry association } \\
\text { Anad -national association for diabetes care } \\
\text { Whole grain cereal }\end{array}$ \\
\hline
\end{tabular}


More than simple information regarding the use of a certain product, the information contained in labels reflects a set of technological steps, applied knowledge, and efforts for work organization along a value chain that originates from the production of raw material to retail shelves. The set of activities in this chain is viewed as an operational strategy that offers an insight into the study that follows.

Methods that allow the logical identification of activities and interventions at various stages of the supply chain are referred to as Reverse Engineering (Thomopoulos, Croitoru \& Tamani, 2015). Although reverse engineering has been widely applied to computer science, its expertise in food science and engineering is fairly new. From a methodological point of view, Thomopoulos, Croitoru \& Tamani (2015) state that the main challenges are (1) The difficulty of definition with exactness as specifications of the final product, given the quality criteria that are both questionable and non-retarded; (2) The full plenum of all processing steps, and especially a sequence. This is because some steps can add 'invisible' characteristics to the final product.

Reverse Engineering (RE) may be described as a set of techniques that allows the reproduction of a product by identifying attributes, materials and other constructive characteristics (Ingle, 1994). The RE methodology constitutes a product-oriented deconstruction technique to identify manufacturing characteristics, composition and valuation attributes (Otto and Wood, 1998).

The information collected from the labels served as an input to the research process that was based on $\mathrm{RE}$. In this process, the following tools were used: bibliographic research, expert consultation, documentary research in Brazilian legislation and search for complementary information on the internet. The purpose of this process was to understand, through a logic causal relationship, how these variables reflect in manufacturing processes and beyond them. E.g., a literature review and consultation with food engineers sought to better understand what "cold pasteurization" was. Two alternatives were identified, (1) High-pressure application (Garcia-Gonzalez et al., 2007; WeltiChanes, Ochoa-Velasco \& Guerrero-Beltrán, 2009), and (2) Irradiation (Loaharanu, 1996). Brazilian legislation, through Resolution 21/2001 of the National Health Surveillance Agency (ANVISA), an agency linked to the Ministry of Health, establishes that irradiated foods should include in their label the description "Food treated by irradiation process" (Brazil, 2001). As this information was not identified in the analyzed label, it was considered the first alternative, the application of high-pressure.

The following questions guided the research and consultation process: What are the known processes used in the manufacturing of products that belong to this category? Do these technologies meet the characteristics expressed in the label analyzed? Which process parameters can be directly linked to the declarations found? Does this product have something innovative? Does this innovation take place in terms of formulation, process, or management? Among the information contained in the labels, what draws the most attention? The search script is shown in Figure 3. The filter questions served as a guide for searching and querying about the different label claims identified. For each product analyzed, the cycle of questions was repeated.

The implications of the label claims were initially classified into ten categories: Marketing, Formulation, Packaging, Process Technology, Production System, Lean Production, Certification, Welfarism, Social Impact, and Origination Strategy. The discussion of results is in the following section. 


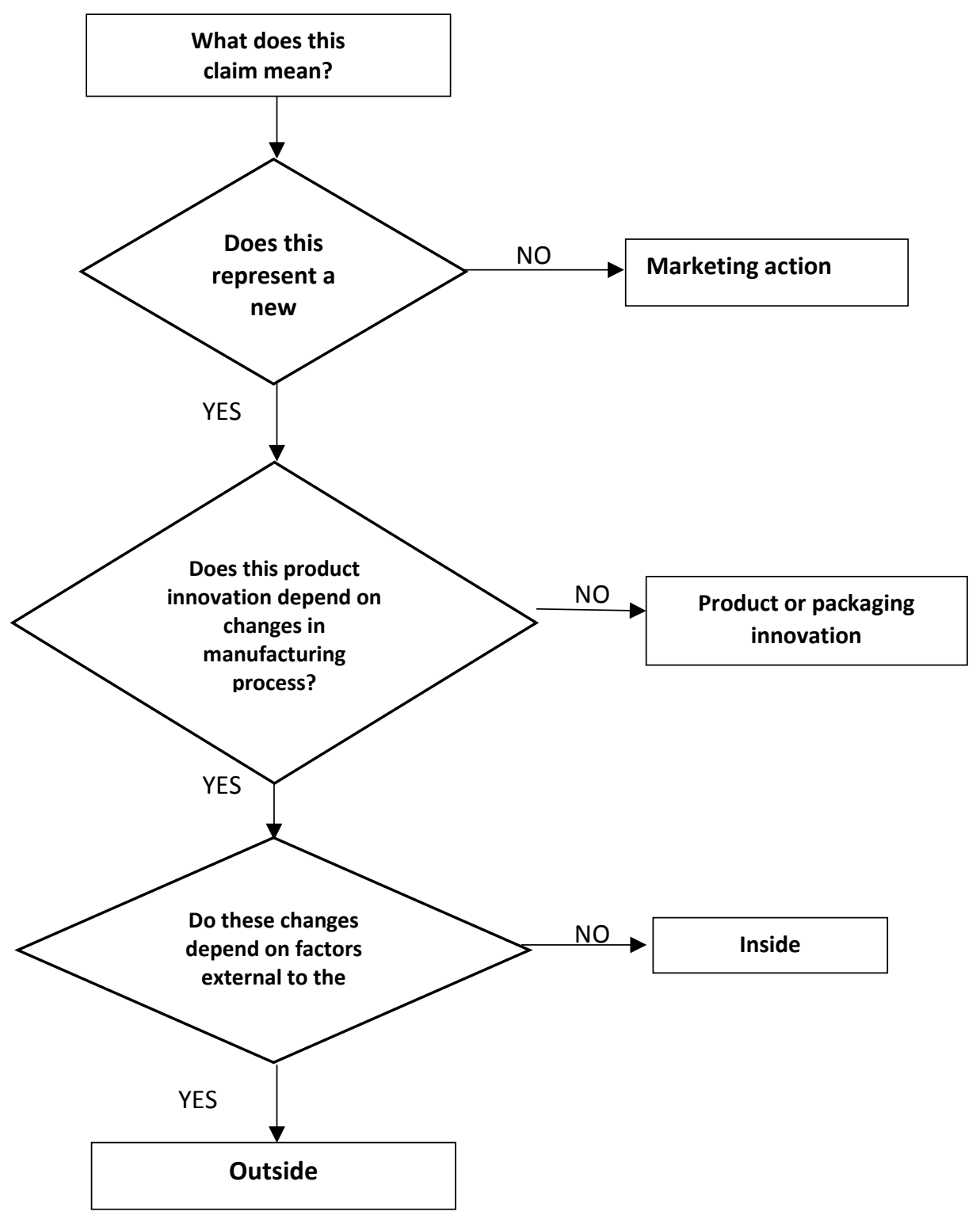

Figure 3. Research roadmap reverse engineering.

\section{Results and Discussion}

The results obtained are aligned with the food ethics two-branch decision model (Figure 2) in terms of product, process, marketing, and packaging (inside perspective) in addition to food processing industry relationships in the value chain (outside perspective).

Label analysis indicated that the differentiation of food and beverage products in terms of food ethics through product and process engineering may be associated with innovations in formulations, productive processes, packaging, and marketing. These developments are presented among new entrants and already leader brands in the market. Examples of this trend may be found in the beverage or the bakery product segments, respectively considering the juices and snacks categories. Table 4 summarizes the results found in the content analysis in labels of the four categories studied. 
Categories (frequency)

\begin{tabular}{l|l|l|l|l}
\hline Asset & Juices & Snacks & Chocolates & Yogurt \\
\hline Flavor & $76 \%$ & $54 \%$ & $84 \%$ & $83 \%$ \\
\hline Nutrition and Health & $37 \%$ & $68 \%$ & $13 \%$ & $29 \%$ \\
\hline Publicity e marketing & $11 \%$ & $13 \%$ & $12 \%$ & $14 \%$ \\
\hline $\begin{array}{l}\text { Processing or manufacturing } \\
\text { mode }\end{array}$ & $9 \%$ & $8 \%$ & $7 \%$ & $4 \%$ \\
\hline Origins and supply chain & $23 \%$ & $6 \%$ & $17 \%$ & $13 \%$ \\
\hline Philanthropy or social action & $3 \%$ & $22 \%$ & $19 \%$ & - \\
\hline Convenience & $68 \%$ & $12 \%$ & $17 \%$ & $31 \%$ \\
\hline Environmental & $97 \%$ & $99 \%$ & $97 \%$ & $99 \%$ \\
\hline Stamps and certificates & $17 \%$ & $5 \%$ & $37 \%$ & $14 \%$ \\
\hline Total Sample & 36 & 115 & 12 & 115 \\
\hline
\end{tabular}

Table 4. Occurrences of claims in terms of product category and positioning (label claims).

In the snacks category, baked products made with non-artificial, whole and organic ingredients, with reduced sodium and fat were highlighted. About $68 \%$ of the snack labels analyzed presented some type of claim in this respect (reduction of ingredients). In the beverages category, new drivers of consumption indicated a trend towards juices with no added preservatives, sugar or water, with $37 \%$ of the analyzed labels containing information on no added sugars and conservatives. Additionally, juices processed using milder technologies are also in demand due to the fact that the preservation of sensory attributes that are original to the raw material is possible - cold pasteurization case cited above.

Regarding innovations in packaging and marketing, the label analysis indicated the use of new packaging formats, colors, and sizes as differentiation strategies. Packs containing a social or environmental appeal were highlighted as trends. In this respect, it should be noted that the environmental issue stands out from label claims, with $98 \%$ of the products analyzed containing some information related to recycling, reduction of packaging material or disposal instructions. In the case of social claims, this percentage was of around $15 \%$. Once again, the snacks category presented important examples concerning this trend. In response to criticism over the encouragement of excessive consumption by family-sized packaging, food products in the snacks category present sharing suggestions ("sharing is fun") in order to reduce the portion consumed.

Despite the particularities of each category, the developments described above converge to a common denominator: the differentiating elements were assured within technological limits (product, process, marketing, and packaging). These differentiating elements do not present any direct results in terms of raw material procurement (associated with variety and origin), nor in terms of the relationship established with suppliers (associated with bases of governance, considering incentive and control, in order to obtain desired quality attributes).

Nonetheless, this is not the only form of action in order to promote the differentiation of food and beverage products. In fact, label analysis indicated that differentiation strategies go beyond aspects assured inside or within technological limits. As evidenced by the analysis conducted, retail shelves are increasingly supplied with brands that promote the health and well-being of the society and the environment in which the company operates. This a premise that marks the contemporary action of the food industry and that already materializes in Brazilian retail shelves as further discussed.

From the perspective of differentials built in terms of industry relationships in their value chain, the differentiation of food and beverage products seems 
to materialize through three main drivers: (1) the development of social and environmental welfare programs, (2) the use of certifications, as well as (3) origin strategies. Examples of such drivers may be found in the beverage, chocolate, and dairy product segments, particularly considering the juices, chocolate and yogurt categories.

The first driver involves the development of social and welfare programs. In addition to welfare initiatives, brand differentiating strategies in terms of food ethics and guided by environmental aspects may also be associated with initiatives of cleaner production standards and reduction of environmental impact. The most expressive manifestation in the analyzed labels relates to the form of packaging discard (98\%). Highlights include label claims such as "recyclable aluminum", "recyclable packaging", "recyclable steel" and "selective waste", present on almost all labels.

In turn, social aspects are less evident. The social engagement of food companies is more present in their advertising material and corporate documents than in their labels. Indeed, label claims analyzed highlighted the encouragement of a healthy life and consumer welfare, without regard to aspects of corporate social responsibility along with their production chain. This is the case of a trend in food products called "better-for-you", highlighting the relevance of actions such as "practice physical exercises", "have healthy habits" and "enjoy your free time". Under this strategy, the health appeal is combined with the mandatory nutritional table, in order to give prominence to the reductions in amounts of sugars, fat, and sodium in certain portions of food. In some cases, a color code is used to classify these components as low, medium and high.

The second driver refers specifically to the relationship of the food industry with its partners, involving public and private certificates of human and social development. Although this positioning is still modestly employed in the Brazilian market, certain initiatives may not be overlooked, such as the organic certification one. In Brazil, certification of organic products is carried out by a certified organization, duly accredited by the Ministry of Agriculture, Livestock, and Supply (MAPA) and accredited by the National Institute of Metrology, Standardization and Industrial Quality (Inmetro). The certification shall be in the form of a seal affixed or printed on the label or packaging of the product. It is common to find labels of organic products containing the MAPA seal and also the seal of the private certifier. In the case of coffee, the most expressive segment in this trend, about $8 \%$ of the labels analyzed had an organic certification.

Fairtrade certification is more common in coffee and chocolate labels. Our hypothesis is that these products are more likely to be successful in strategies of differentiation and sophistication. It was also noted that these certifications, as well as the Rainforest Alliance one, appear mostly in labels of companies operating in the international market, as observed by Loureiro \& Lotade (2005) and Jaffee (2008). Veiga, Makishi \& Zacareli (2016) described that some corporate standards can be adopted internationally regardless of the incentives from the local market. The same is true for some private standards created by the companies themselves, such as Nestlé's Cocoa Plan seal.

Certifications issued by associations of class were also observed, such as the National Association of Attention to Diabetes and Brazilian Association of Cardiology. These arrangements escape the set of traditional corporate stakeholders.

Finally, the label analysis shows that the differentiation of products in retail shelves is also largely guided by geographical and territorial identity issues, constituting the third driver. This driver is associated with the identification and enhancement of specific local attributes. For example, terroir in wines is a strategy that unfolds as a formal structure of origin, such as Geographical Indication and Denomination of Origin. In most cases of non-formal denomination, there is no third party certifying the origin of the raw materials used and the declaration of origin is provided exclusively by the manufacturer.

Once again, coffee labels stand out concerning this strategy. Regions such as Mogiana, Cerrado Mineiro, Águia Branca, and Serra da Mantiqueira are considered references regarding coffee production in Brazil and displaying these regions on labels has been used as a differentiation strategy. Similarly, countries such as Ecuador, Colombia, Venezuela, and Switzerland are considered references regarding chocolate production and the attribution of origin to these regions consists of an important differentiation strategy.

Concerning this differentiation base, origin, form of confinement, animal breed and other factors 
interfere decisively in the quality of the final product. A differentiated raw material is necessarily obtained through particularly coordinated supply sources, in terms of the relationship with producers. This particular movement is still considered a niche in Brazil, restricted to premium products that are commercialized in specific channels. Nevertheless, a closer look evidences the start of a movement of dissemination of brands known to be differentiated, suggesting the start of a dispute for space in the shelf of supermarkets with conventional products aimed at the public in general.

\section{Managerial Implications}

This study shows a movement of food ethics brand differentiation structured in two main branches: inside perspective (product, process, marketing, and packaging) and outside perspective (food industry relationships in the value chain).

It is worth highlighting that differentials associated with the inside perspective must be protected through patents or other entrance barriers, such as required capital for research and development or brand value. Otherwise, the existing differential inevitably equals.

From this view, the outside perspective can be a powerful alternative. New rules of global competition and a more informed consumer force companies to build, through collaborative relationships with suppliers, producers, distributors and customers, a strategy to create competitive advantage and differentiation to the entire value chain in terms of quality, sustainability, safety and efficiency (Mangina; Vlachos, 2005; Manzini; Accorsi, 2013).

At the core of differentiation is the relation established between the quality of the processed food, the origin of the raw material, and the bases of relationships with the rural producer. This association meets the longing for sustainable competitive advantages due to the fact that it represents a nonreplaceable and difficultly copied differentiating element in a short time by the competition, because of the unique character of the relationship in question (Barney, 1991).

Evidently, this choice of a path should not be understood as an organizational detachment. Differently, adapting and adjusting effectively to conceptions of products more suited to social pressure represents an important business for the food industry. At the front of this process is the consumer, which is strengthened by both the power of instant exchange of information via social networks, as well as by the increasing offer of products with differentials based on ethical aspects.

\section{Final Remarks}

The main goal of this paper was to evaluate how the concept of food ethics materializes in processed foods and beverages in Brazil through a label analysis using a reverse engineering methodology.

Regarding the Brazilian food and beverage industry, the label analysis indicates that the differentiation strategy used is mainly associated with the inside perspective, suggesting important opportunities for the industry in Brazil. Indeed, despite the particularities of each category, the developments described in this paper converge to a common denominator: most of the differentiating elements were assured within technological limits (product, process, marketing, and packaging). These differentiating elements do not present any direct results in terms of raw material procurement (associated with variety and origin) nor in terms of the relationship established with suppliers (associated with bases of governance, considering incentive and control, in order to obtain desired quality attributes).

In contrast, the competitive strategies used by the food industry have pointed to the need for an increasingly fine design of the systemic relationships that define the value chain. Innovation in terms of products and processes within the firm is still a hallmark of business strategies in the food industry, but aspects such as ethics and social responsibility require novel structural innovations that extend beyond the firm's boundaries, involving management and relationship engineering. Besides, the industry has to develop closer relationships with suppliers in order to advance in outside aspects, such as social justice, terroir enhancement and preservation of raw material attributes.

Nevertheless, this article presented limitations that may indicate future research opportunities. One particular limitation is that the results presented were found in a midsize retailer located in a mediumhigh consumption region. Brazil is a country of continental dimensions, with very heterogeneous traditions and consumption habits. The food industry, as well as other business segments, has recognized this fact and directed its strategies to local contexts. 
Likewise, the authors find it interesting to conduct similar research in other locations.

One speculation worth investigating is whether this movement is predominantly an important gateway to new and small entrants; which in turn force brand and market repositioning of companies already consecrated in the market. Furthermore, this discussion indicates an interesting future research agenda, starting with the investigation of the organizational determinants for investment in actions outside of brand differentiation and the relevance of small businesses as a starting point. In this sense, the paper opens room for the analysis of the real benefits of food ethics to agents in food value chains, as well

\section{References}

Abras_Brazilian Association of Supermarkets (2019). Sector Information. Department of Economics and Research. Retrieved from: http://www.abrasnet.com.br. Accessed 01 May 2019.

Aguilera, J. M. (2006), Perspective Seligman Lecture 2005 Food product engineering: Building the right structures, Journal of the Science of Food and Agriculture, 86, 1147-1155.

Ahvenainen, R. (2003). Novel food packaging techniques. CRC Press, Boca Raton.

Barney, J. (1991). Firm resources and sustained competitive advantage, Journal of management, 17(1), 99-120.

Beekman V. (2000) You are what you eat: Meat, novel protein foods and consumptive freedom. Journal of Agricultural and Environmental Ethics 12(2):185-196.

Bissinger, K., \& Leufkens, D. (2017). Ethical food labels in consumer preferences, British Food Journal, 119(8), 1801-1814.

Boehe, D. M., \& Cruz, L. B. (2010). Corporate social responsibility, product differentiation strategy and export performance, Journal of Business ethics, 91(2), 325-346.

Brazil. Agência Nacional de Vigilância Sanitária ANVISA. Resolução no 21, de 26 janeiro 2001. Retrieved from: http://anvisa.gov.Br/legis/resol/ 21_01rdc.htm. Accessed 12 Out 2018.

Brom, F. W. A. (2000). Food, consumer concerns, and trust: Food ethics for a globalizing market, Journal of Agricultural and Environmental Ethics, 12, 127-139. as for the study of how this differentiation strategy could benefit them.

\section{Acknowledgements}

The authors would like to thank the Center for Organization Studies (CORS), as well as the Group of Studies and Research on Strategy and Vertical Coordination (GEPEC) for providing a rich environment for the development of this study. Our special thanks to Camille Valle for her dedication and efforts in the initial phase of data collection process. Last but not least, we would like to thank the Brazilian National Council for Scientific and Technological Development (CNPq), for funding this study (Universal Project, Process 407 498/2016-8).

Brug, J., Debie, S., Assema, P. \& Weijts, W. (1995). Psychosocial Determinants of fruit and vegetable consumption among adults: Results of focus group interviews. Food Quality and Preference, 6(2), 99-107.

Caswell, J. A., \& Mojduszka, E. M. (1996). Using informational labeling to influence the market for quality in food products. American Journal of Agricultural Economics, 78(5), 1248-1253.

Chan, C., Patch, C., \& Williams, P. (2005). Australian consumers are sceptical about but influenced by claims about fat on food labels. European Journal of Clinical Nutrition, 59(1), 148-151.

Coff, C. (2013). A semiotic approach to food and ethics in everyday life, Journal of Agricultural and Environmental Ethics, 26(4), 813-825.

Deblonde, M., de Graaff, R., \& Brom, F.J Agric environ ethics. (2007). Journal of Agricultural and Environmental Ethics. 20, 99-118. Doi: 10.1007/s10806006-9019-4.

De Tavernier, J. (2012). Food citizenship: Is there a duty for responsible consumption?, Journal of Agricultural and Environmental Ethics, 25, 895-907.

Du, S., Bhattacharya, C., \& Sen, S. (2007). Reaping relational rewards from corporate social responsibility: The role of competitive positioning, International Journal of Research in Marketing, 24, 224-241.

Early, R. (2002). Food ethics: A decision making tool for the food industry? International Journal of Food Science and Technology, 37(4), 339-349.

Euromonitor. (2014). Corporate strategies in health and wellness: Part 1 focus developed markets. Retrieved from: http://www.euromonitor.com. Accessed $30 \mathrm{Nov}$ 2017. 
Feunekes, G. I., Gortemaker, I. A., Willems, A. A., Lion, R., \& Van Den Kommer, M. (2008). Front-of-pack nutrition labelling: testing effectiveness of different nutrition labelling formats front-of-pack in four European countries. Appetite, 50(1), 57-70.

Garcia-Gonzalez, L., Geeraerd, A. H., Spilimbergo, S., Elst, K., Van Ginneken, L., Debevere, J., ... \& Devlieghere, F. (2007). High pressure carbon dioxide inactivation of microorganisms in foods: the past, the present and the future. International Journal of Food Microbiology, 117(1), 1-28.

Govindan, K. (2018). Sustainable consumption and production in the food supply chain: A conceptual framework. International Journal of Production Economics, 195, 419-431

Green, P. \& Srinivasan, V. (1978). Conjoint analysis in consumer research: Issues and outlook, Journal of Consumer Research, 5(2), 103-123. Doi: 10.1086/208721.

Green P.E. \& Srinivasan V., (1990). Conjoint analysis in marketing: New developments with implications for research and practice. Journal of Marketing, 54, 3-19.

Grunert, K. G., Hieke, S., \& Wills, J. (2014). Sustainability labels on food products: Consumer motivation, understanding and use. Food Policy, 44, 177-189.

Grunert K.G., Baadsgaard, A., Larsen H.H. \& Madsen T.K., (1996), Market orientation in food and agriculture. Boston, Kluwer Academic.

Henson, S., \& Humphrey, J. (2009). The impacts of private food safety standards on the food chain and on public standard-setting processes, Joint FAO/WHO Food Standards Programme, Codex Alimentarius Commission, Third-second Session, Rome, 29 June - 4 July 2009.

Hepting, D. H., Jaffe, J., \& Maciag, T. (2014). Operationalizing ethics in food choice decisions, Journal of Agricultural and Environmental Ethics, 27, 453-469.

Hodgkins, C., Barnett, J., Wasowicz-Kirylo, G., StyskoKunkowska, M., Gulcan, Y., Kustepeli, Y. \& Gibbs, M. (2012). Understanding how consumers categorise nutritional labels: a consumer derived typology for front-of-pack nutrition labelling. Appetite, 59(3), 806817.

Humphrey, J. \& Memedovic, O. (2006). Global value chains in the agrifood sector. Available at: http://tinyurl.com/y8qh4obd. 16 April 2019.
Irvine, R. (2013). Food ethics: Issues of consumption and production, Journal of Bioethical Inquiry, 10(2), 145148.

Janßen, D., Langen, N., (2017). The bunch of sustainability labels - Do consumers differentiate? Journal of Cleaner Production, 143, 1233-1245.

Jaffee, D. (2008). Better, but not great: the social and environmental benefits and limitations of Fair Trade for indigenous coffee producers in Oaxaca, Mexico'. In: Ruben, R. (ed.) The impact of Fair Trade. Academic Publishers, Wageningen.

Ingle, K. (1994). Reverse engineering. McGraw-Hill, Inc., New York.

Kasemodel, M. G. C., Makishi, F., Souza, R. C., \& Silva, V. L. (2016). Following the trail of crumbs: A bibliometric study on consumer behavior in the Food Science and Technology field, International Journal of Food Studies, 5, 73-83.

Korthals, M. (2001), Taking consumers seriously: Two concepts of consumer sovereignty, Journal of Agricultural and Environmental Ethics, 14, 201-2015.

Loaharanu, P. (1996). Irradiation as a cold pasteurization process of food. Veterinary Parasitology, 64(1-2), 71-82.

Lopez, J. (2014) Changing role of business. Creating Shared Value Forum 2014. Retrieved from: https://www.youtube.com/watch?v=SOz5Qw1kc84.

Loureiro, M. L., \& Lotade, J. (2005). Do fair trade and eco-labels in coffee wake up the consumer conscience? Ecological economics, 53(1), 129-138.

Mangina, E., \& Vlachos, I.P. (2005), The changing role of information technology in food and beverage logistics management: beverage network optimization using intelligent agent technology, Journal of Food Engineering, 70(3), 403-420.

Manzini, R., \& Accorsi, R. (2013), The new conceptual framework for food supply chain assessment, Journal of Food Engineering, 115(2), 251-263.

Marsh, K., \& Bugusu, B. (2007). Food packaging: Roles, materials, and environmental issues. Journal of food science, 72(3), 39-55.

Melo, M.F.S., Sproesser, R.L., Campos-Silva, W.L.; Piao, R.S. (2018). Business strategy and environmental practices: Evidence in the sugarcane energy sector in Brazil. African Journal of Business Management, 12, 4457. 
Mintel. (2016). Global Food and Drink Trends 2016. Mintel. Retrieved from https://www.mintel.com/presscentre/food-and-drink/mintel-identifies-global-foodand-drink-trends-for-2016.

Mintel. Global New Product Database. Mintel. (2017). Retrieved from http://brasil.mintel.com/gnpdbanco-de-datos-de-novos-productos.

Nancarrow, C., Wright, T.L. \& Brace, I. (1998). Gaining competitive advantage from packaging and labeling in marketing communications. British Food Journal, 100(2), 110-8.

Neumark-Sztainer, D., Story, M., Perry, C. \& Casey, M.A. (1999). Factors influencing food choices of adolescents: findings from focus-group discussions with adolescents. Journal of the American dietetic association, 99(8), 929-937.

Otto, K. \& Wood, K. (1996). A reverse engineering and redesign methodology for product evolution. Proceedings of the ASME Design Theory and Methodology Conference, Irvine, CA.

Prendergast, G., \& Pitt, L. (1996). Packaging, marketing logistics and the environment: are there trade-offs? International Journal of Physical Distribution \& Logistics Management, 26(6), 60-72.

Rettie, R. \& Brewer, C. (2000). The verbal and visual components of package design. Journal of Product \& Brand Management, 9(1), 56-70.

Robertson, G.L. (2012). Food packaging: principles and practice. CRC Press, Boca Raton.

Rodrigues, D.B., Dalmarco, D. A. S., Aoqui, C., Marinho, B. L. (2016). The meaning of the organic certification label for the consumer: a cluster analysis. REGE-Revista de Gestão, 23, 316-325.

Saes, M.S.M., Silva, V.L., Nunes, R., \& Gomes, T.M. (2014). Partnerships, learning, and adaptation: A cooperative founded by Japanese immigrants in the Amazon rainforest. International Journal of Business and Social Science, 5, 131-141.

Saguy, S., Singh, R.P., Johnson, T., Fryer, P.J., \& Sastry, S.K. (2013). Challenges facing food engineering, Journal of Food Engineering, 119(2), 332-342.

Sarantopoulos, C.I.G.L., De Oliveira, L.M., Canavesi, E. (2001). Requisitos de conservação de alimentos em embalagens flexiveis. CETEA/ITAL.

Severo, E.A.; Guimarães, J.C.F.; Dorion, E.C.H. (2018). Cleaner production, social responsibility and ecoinnovation: generations' perception for a sustainable future. Journal of Cleaner Production, 186, 91-103.
Shine, A., O'Reilly, S., \& O'Sullivan, K. (1997). Consumer use of nutrition labels. British Food Journal, 99(8), 290-296.

Silayoi, P. \& Speece, M. (2007). The importance of packaging attributes: a conjoint analysis approach. European Journal of Marketing, 41(11/12), 1495-1517. Doi: 10.1108/03090560710821279.

Silva, V.L. (2017). Olhando fora da caixa: estratégia de diferenciação e governança de relacionamentos na indústria de alimentos. 1st ed. Portal de Livros Abertos da USP. Retrieved from: http://www.livrosabertos.sibi.usp.br/portaldelivrosUSP /catalog/book/138. Doi:10.11606/9788566404098.

Silva, V. L., Sereno, A.M., \& Sobral, P.J.A. (2018). Food Industry and processing technology: On Time to Harmonize Technology and Social Drivers, Food Engineering Doi: https://doi.org/10.1007/s12393-017-9164-8.

Smith, J.P., Ramaswamy, H.S., Simpson, B.K. (1990). Developments in food packaging technology. Part II. Storage aspects. Trends in Food Science \& Technology, 1, 111-118.

Thomopoulos, R., Croitoru, M., \& Tamani, N. (2015). Decision support for agri-food chains: A reverse engineering argumentation-based approach. Ecological Informatics, 26, 182-191.

Vale, D., Morais, C. M. M. D., Pedrosa, L. D. F. C., Ferreira, M. Â. F., Oliveira, Â. G. R. D. C., \& Lyra, C. D. O. (2019). Correlação espacial entre o excesso de peso, aquisição de alimentos ultraprocessados e o desenvolvimento humano no Brasil. Ciência \& Saúde Coletiva, 24, 983-996.

Van der Pol, M. \& Ryan, M. (1996). Using conjoint analysis to establish consumer preferences for fruit and vegetables. British Food Journal, 98(8), 5-12. Doi: https://doi.org/10.1108/00070709610150879.

Vecchio, R. \& Annunziata, A. (2015). Willingness-topay for sustainability-labelled chocolate: An experimental auction approach. Journal of Cleaner Production, 86, 335-342. Doi: 10.1016/j.jclepro.2014.08.006.

Veiga, J. P. C., Makishi, F., \& Zacareli, M. A. (2016). Corporate Leadership, Multilevel Enforcement and Biodiversity Regulation, Journal of Business, 1(3), 43-53.

Verbeke, W., \& Ward, R.W. (2006). Consumer interest in information cues denoting quality, traceability and origin: An application of ordered probit models to beef labels. Food Quality and Preference, 17(6), 453-467. 
Viana, M.V., Silva, V.L., \& Trindade, M.A. (2014). Consumers' perception of beef burgers with different healthy attributes. Lebensmittel-Wissenschaft + Technologie / Food Science + Technology, 1227-1232.

Welti-Chanes, J., Ochoa-Velasco, C.E., \& GuerreroBeltrán, J.A. (2009). High-pressure homogenization of orange juice to inactivate pectinmethylesterase. Innovative Food Science \& Emerging Technologies, 10(4), 457-462.
World Food Summit (1996). Food security. FAO's Agriculture and Development Economics Division. Retrieved

from:http://www.fao.org/fileadmin/templates/faoitaly /documents/pdf/pdf_Food_Security_Cocept_Note.pdf. Accessed 01 May 2019.

Zatorre, R. (2005). Music, the food of neuroscience? Nature, 434(7031), 312.

\section{ABOUT AUTHORS}

- Vivian Lara Silva - Universidade de São Paulo - USP, São Paulo, (Brasil). E-mail: vivianlara@usp.br Orcid id: https://orcid.org/0000-0001-9849-8043

- Marcia Gabriela C. Kasemodel - Universidade de São Paulo - USP, São Paulo, (Brasil). E-mail: marciakasemodel@gmail.com Orcid id: https://orcid.org/0000-0003-2341-2609

- Fausto Makishi - Universidade Federal de Minas Gerais - UFMG, Minas Gerais, (Brasil). E-mail: faustomakishi@gmail.com Orcid id: https://orcid.org/0000-0003-3154-9357

- Roberta de Castro Souza Pião - Universidade de São Paulo - USP, São Paulo, (Brasil). E-mail: faustomakishi@gmail.com Orcid id: https://orcid.org/0000-0001-9849-8043

- Vinícius Machado dos Santos - Universidade de São Paulo - USP, São Paulo, (Brasil). E-mail: vinicius5.santos@usp.br Orcid id: https://orcid.org/0000-0002-6477-0595 


\title{
QUEM VÊ CARA, VÊ CORAÇÃO: ÉTICA ALIMENTAR E AS CONSEQUÊNCIAS PARA CADEIA DE VALOR
}

\author{
Vivian Lara Silva, Marcia Gabriela C. Kasemodel, Fausto Makishi, Roberta de Castro Souza Pião, Vinícius Machado dos Santos \\ Universidade de São Paulo - USP, São Paulo, (Brasil) \\ Universidade Federal de Minas Gerais - UFMG, Minas Gerais, (Brasil)
}

\begin{tabular}{l}
\hline DETALHES DO ARTIGO \\
\hline Histórico do Artigo: \\
Histórico do Artigo: \\
Recebido em: 18 de dezembro de 2018 \\
Aceito: 21 de julho de 2019 \\
Disponível online: 01 de agosto de \\
2019 \\
Sistema de revisão "Double blind \\
review” \\
Editor Científico \\
Ilan Avrichir \\
Palavras-Chave \\
Produtos Alimentícios; \\
Inovação; \\
Criação de Valores; \\
Rotulagem da Estratégica Alimentar
\end{tabular}

\begin{abstract}
RESUMO
O contexto contemporâneo da indústria de alimentos instiga uma nova concepção de produto, relacionada à ética alimentar. Mas como esse reposicionamento se materializa nas gôndolas das redes varejistas? A fim de trazer elementos a essa discussão, este artigo apresenta um estudo exploratório baseado na decodificação das informações contidas nos rótulos de alimentos comercializados no Brasil. No total, foram analisados 287 rótulos referentes a quatro categorias (sucos, lanches, chocolates e iogurtes). Os resultados indicam um movimento de diferenciação estruturado em ações realizadas 'inside' (resultado da engenharia de produto e de processo) e 'outside' (engenharia de relacionamentos ao longo da cadeia de valor). Em outras palavras, diferenciais equacionados internamente, nos limites da firma, referindose a inovações em produto e processo, mas também podendo referir-se ao desenvolvimento de relações de cooperação e coordenação ao longo do sistema produtivo em que se insere o processamento. Estratégia em que a participação em mercados globalmente conectados emerge como um direcionador de diferenciação em relação a aspectos éticos na indústria de alimentos e tem efeitos diretos sobre as estruturas verticais das firmas, conforme sugerido pela literatura de cadeia de valor.
\end{abstract}

\section{Cite it like this:}

Silva, V., Kasemodel, M., Makishi, F., Pião, R., \& Santos, V. (2019). Beauty is not Only Skin Deep: Food Ethics and Consequences to the Value Chain. Internext, 14(3), 286-303. doi:http://dx.doi.org/10.18568/internext.v14i3.489 